\title{
Alfabetização: desafios e necessidades
}

Mirian Bispo Moreira: Atualmente cursa graduação em Pedagogia na Faculdade de Educação da Universidade de São Paulo.
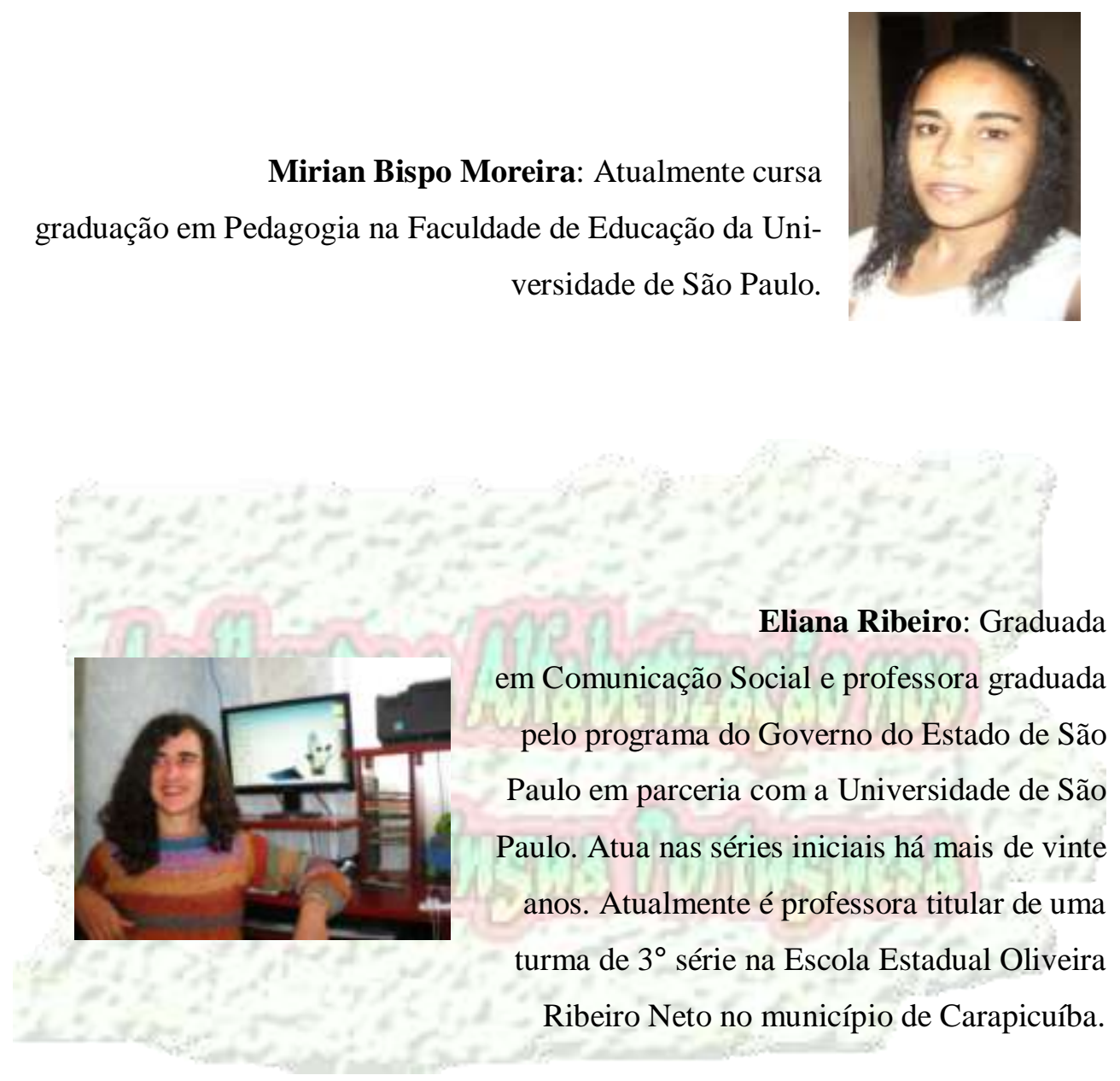

Mirian: Qual a importância da alfabetização e do letramento?

É importante porque está formando cidadãos; letramento, principalmente, porque não basta apenas saber a ler e escrever. Porque infelizmente o que nós temos visto é que muitas pessoas chegam ao final da Educação Básica só sabendo ler e escrever o nome. Uma coisa que parece que está arraigado nos estudantes é essa cultura de não aceitar desafios. Nós professores 
somos convidados a desafiar e os alunos não querem aceitar esses desafios. Então é importante o letramento para o indivíduo ter um vínculo social ser cidadão. Outra coisa importante em relação ao letramento já que estamos falando em eleição é a questão política. Pelo menos, começar um processo de politização, desejar que eles sejam seres completamente politizados é muita coisa, mas pelo menos iniciar esse processo. Precisamos de seres humanos politizados neste país.

Mirian: Quais são os desafios e dificuldades nesse processo de alfabetização.

Eliana: As dificuldades e os desafios são muitos, iniciando pelo aspecto profissional. A valorização do magistério. Valorização que implica em salários dignos para que os estudantes tenham vontade de ser professores, porque todos fogem e com razão. Apesar de alguns especialistas defenderem que não é necessário discutir esse tema, mas é necessário, pois a valorização do profissional se inicia com um salário digno. Estava pensando, ultimamente, que, mesmo no ensino de primeira a quarta, o ensino deveria ser dif vidido por áreas assim como é no secundário com os especialistas por áreas. Por que um professor polivalente que dê conta de todo o conteúdơ? Porque não damós-conta de tudo porque somos muito mat formados. Tem coisas que você não sabe. Em Matemática, principalmente, temos visto nos resultados do Saresp ${ }^{1}$, as dificuldades dos alunos principalmente nessa disciplina e, muitas vezes, o professor polivalente não tem a especialização efetiva para lidar com essas dificuldades. Investir na formação do professor, bons salários, redução do número de alunos por sala. Não dá para lotar uma sala de alunos e exigir que você trabalhe sem que haja dificuldades, isso, na prática, não existe e não é por falta de dedicação do professor, mas não dá para

\footnotetext{
${ }^{1}$ Sistema de Avaliação de Rendimento Escolar do Estado de São Paulo.
} 
ignorar as dificuldades e o tempo de aprendizagem do aluno. Outra dificuldade é a falta de continuidade das políticas educacionais, cada vez que muda o secretário de Educação, troca-se também esses planos, mesmo dentro do mesmo partido. Esse último projeto "Ler e Escrever", a meu ver, é um fracasso, porque engessa os professores que são obrigados a seguir o guia que supõe o que é melhor para as crianças. De fato, há atividades muito interessantes que, porém, na prática não funcionam. Normalmente, os coordenadores exigem que seja implantado esses programas sem nenhum tipo de flexibilização que atenda às necessidades reais dos alunos. Até queria trabalhar mais, antigamente tinha a liberdade para preparar as aulas era até mais trabalhoso, pesquisava aqui e ali. Mas agora não, todo aquele guia, o aluno aprendendo ou não tem que ser aquilo. O material é maravilhoso, más na prática nem sempre funciona e o professor deveria ter, no mínimo, a liberdade para adaptar.

Mirian: Quais são os elementos necessários para que o processo de alfabetização e letramento seja efetivo?

Eliana: Na verdade, é necessário um conjunto de fatores para que de fato o processo ocorra. Acredito que haja fatores cognitivos que tenham forte influencia, porém não vou me-aprofundar nessa questão por não ter condições de discorrer sobre isso. Acho que um dos fatores que dificultam a aprendizagem é a falta de estímulo em casa. A criança não tem estímulo em casa, não tem que leia uma historinha para ela, quem dê uma atividade prazeroas, mas que vai estimular a aprendizagem, ninguém tem coragem de se quer ver se a criança fez sua lição de casa. Outra questão que já citamos é o fato das salas estarem superlotadas, e o professor não dá a atenção necessária que requer aquela criança. Além do método utilizado pelo professor que pode facilitar ou dificultar esse processo.

Mirian: Qual é o papel da família para que o processo seja efetivo? 
Eliana: A família é coadjuvante, é um dos elementos necessários para que ocorra, de fato, a educação. O professor, o aluno e a família são esses elementos. A partir do momento que um desses sai do eixo, a coisa não anda, não tem sucesso. Temos observado é, cada vez, um maior distanciamento da família em nome a uma rotina cada vez mais suprimida pela correria do dia a dia e pelos encargos do trabalho e sobra pouco ou quase nenhum tempo para os pais acompanharem e aconselharem os filhos. Precisaria de uma participação efetiva dos pais, para ajudar a criança, pois a criança precisa sentir que tem utilidade para a vida deles tanto na sala de aula como na família. Eles, as crianças, estão completamente largados. Normalmente, não trazem os materiais necessários para realizar uma ou outra atividade com a desculpa de não ter dinheiro e, para outras coisas, como lanches industrializados, eles têm dinheiro para isso.

\section{Autora:}

Mirian Bispo Moreira

Contato: mirianflgpray@gmail.com

Entrevista recebida em novembro de 2010.

Entrevista aprovada para publicação em janeiro de 2011.

\section{Como citar esta entrevista:}

Moreira, M. B.. Alfabetização: desafios e necessidades. Revista Acolhendo a Alfabetização nos Países de Língua Portuguesa, Brasil, São Paulo, volume 1, $\mathrm{n}^{\mathrm{o}}$. 11, pp. 184 - 187, Set.. 2011. Disponível em: <http://www.acoalfaplp.net>. 